7.Porfy`r`yev B. N. «Zelenыe» tendency`y`v my`rovoj fy`nansovoj sy`steme. My`rovaya эkonomy`ka y` mezhdunarodnыe otnosheny`ya. 2016. \# 9. S. 5-16. [in Ukrainian].

8. Sunduk A. Analiz zmistovny`x xaraktery`sty`k finansovo-ekonomichnogo regulyuvannya u sferi pry`rodokory`stuvannya. Ekonomist. 2017. \# 12. S. 31-34. [in Ukrainian].

Дата подання публікації 18.06 .2020 p.

УДК 336.02:658.15

Купира М.I., к.е.н., доцент

Kupyra M. Candidate of Economic Sciences, Associate Professor https://orcid.org/0000-0002-8279-7628

Киришко М.В., студент

Kyryshko M. Student

\title{
ФОРМУВАННЯ ФІНАНСОВОЇ СТРАТЕГІЇ В СИСТЕМІ ЗАБЕЗПЕЧЕННЯ КОНКУРЕНТОСПРОМОЖНОСТІ ПІДПРИЕМСТВА
}

\author{
Луцький національний технічний університет
}

У статті доведено, що формування фінансової стратегії як основи стійкого та конкурентоспроможного розвитку у довгостроковій перспективі вимагає чітко побудованого алгоритму 3 врахуванням сучасних тенденцій. Встановлено, що під фінансовою стратегією в системі забезпечення конкурентоспроможності підприємства важливо трактувати загальний план окреслення точковості фінансових цілей та завдань на довгострокову перспективу через формування фінансових ресурсів у векторному напрямку фінансовою стійкості.

Проведено теоретичний розбір сутнісного наповнення фінансової стратегії в процесі формування, реалізації та коригування 3 виділенням структурних елементів фінансової стратегії в частині результативності.

Розроблено архітектуру формування фінансової стратегії в системі забезпечення конкурентоспроможності через матричний аналіз та фінансовий ефект.

Доведено, що фінансова стратегія в частині результативності діє через принципи та етапність щодо формування і впровадження та працює за виведеним алгоритмом: Управління = капітал + активи + інвестиції + грошові кошти+ прибуток + ризики. Узгодженість та ефективність управління на кожному етапі створює вектор прибутковості в процесі гнучкої фінансової політики. В першу чергу, в систему закладають достатній обсяг фінансових ресурсів, методи ефективності використання капіталу, оптимізація його структури та швидке реагування й нейтралізація ризиків на довгострокову перспективу.

Запропоновано матрицю вибору фінансової стратегії в частині ефективного стратегічного управління підприємства через синергію та дисбаланс 3 визначеним рівнем ефективності кожного структурного елементу та розраховано фінансовий ефект від вбудованих інноваційних інструментів у фінансову стратегію, який лише підсилить конкурентні позиції підприємства на ринку.

Фактично, фінансова стратегія є тією основою, яка забезпечує векторне фінансове підгрунтя для фінансово-економічного розвитку в частині нарощення прибутковості. Ї̈і ефективність окреслюється моментами, за яких стратегічні цілі грунтуються на реальних фінансових показниках та можливостях підприємства, чіткій системі управління, гнучкості та прозорості.

Ключові слова: фінансова стратегія, стратегічне управління, ефективність, результат, підприємство, прибуток, гнучкість, прозорість, системність.

\section{FORMATION OF FINANCIAL STRATEGY IN THE SYSTEM OF PROVIDING OF COMPETITIVENESS OF ENTERPRISES}

\author{
Lutsk National Technical University
}

The formation of financial strategy as a basis for sustainable and competitive development in the longterm requires an algorithm based on current trends proved in the article. Installed, that the financial strategy in the system of providing competitiveness of enterprise is a general plan of lineation financial goals and tasks on a long-term through forming of financial resources in the vectors direction of financial stability. 
Conducted, the theoretical analysis of the essence filling of financial strategy in the process of forming, realization and correction, with the selection of structural elements of financial strategy in part of effectiveness.

The architecture of forming of financial strategy in the system ensuring of competitiveness through a matrix analysis and financial effect.

It is proved, that the financial strategy in part to the result operates through the principles and stage of formation and implementation and work to the derived algorithm: Management $=$ capital + assets + investments + cash + profit + risks. Consistency and efficiency of management at each stage create a vector of profitability in the process of elastic financial policy. First, in the system includes a sufficient amount of financial resources, methods of effective use of capital, optimization of structure and rapid response and neutralization of risks on long-term.

Offered the matrix of the choice of financial strategy in the part of effective strategic management of the enterprise through synergy and an imbalance with defined level of efficiency of each structural element. Calculated the financial effect of the built-in innovative instruments in the financial strategy, which will only strengthen the competitive position of the enterprise in the market.

In fact, the financial strategy is the basis that provide a vector financial foundation for financial and economic development in terms of growing profitability. Its effectiveness is determine the moments when the strategic goals are base on real financial indicators and capabilities of enterprise, clear-cut management system, flexibility and transparency.

Key words: financial strategy, strategic management, effectiveness, result, enterprise, profit, enterprise, profit, flexibility, transparency, system.

Постановка проблеми у загальному вигляді i iї зв'язок 3 важливими науковими та практичними завданнями. В умовах економічного розвитку обгрунтованість та дієвість сформованої фінансової стратегії залежить в першу чергу від ефективності управлінських рішень в системі фінансового менеджменту, можливості якої визначаються обсягом фінансових ресурсів в напрямку одержання прибуткового кінцевого результату.

Диспропорції змушують підприємства швидко адаптуватись до змін через пошук дієвих інструментів нарощення ефективності своєї діяльності, що напряму залежать від інноваційно-інвестиційної активності та здатності бути конкурентоспроможним за будьяких умов. Доцільність теми роботи в асиметричних умовах розвитку обумовили мету та послідовність теоретичного викладу.

Аналіз останніх досліджень, у яких започатковано вирішення проблеми. Питаннями дослідження проблем визначення та формування фінансової стратегії, вивчення окремих іiі складових, займались багато вчених-дослідників: Ногіна С., Шумікін С., Костанян С., Бас. Ю.В., Волощук Л.О., Іващенко А.І., Воронкова Т.С., Гудзь O.І., Корпан О.С. та інші. Проте, відсутність чіткого алгоритму формування фінансової стратегії в системі забезпечення конкурентоспроможності підприємства 3 подальшої побудовою рекомендаційних кроків потребують детальної систематизації та практичних уточнень.

Цілі статті. Полягають в систематизації та обгрунтуванні теоретико-прикладних засад формування фінансової стратегії в системі забезпечення конкурентоспроможності підприємства.

Виклад основного матеріалу дослідження 3 повним обгрунтуванням отриманих наукових результатів. Формування фінансової стратегії, як складової системи стратегічного управління, сьогодні є важливим етапом в частині забезпечення конкурентоспроможності та стійкості підприємства через ефективну оптимізацію структури капіталу, вектор доходів над сукупними витратами i, як результат посилення факторів до самовідтворення та нарощення фінансового потенціалу.

Подібна ситуація вимагає результативного пошуку видів, інструментів та методів, які б в сукупності працювали стратегічно та створювали умови до ефективного формування фінансових ресурсів. Так, як фінансові ресурси, закладаються в систему під якісно-кількісними показниками формування майна підприємства, тому вони i працюють на довгострокову перспективу в частині капіталізації прибутків товариства.

Саме, «політика формування власних фінансових ресурсів є частиною загальної фінансової стратегії підприємства, що полягає в забезпеченні необхідного рівня самофінансування його виробничого розвитку. Відтак, 3 метою забезпечення 
ефективності управління цим процесом на підприємстві розробляється спеціальна фінансова політика» [1, с. 349], яка є підгрунтям створення синергетичного ефекту в частині якісного фінансового менеджменту.

Погоджуємось 3 думкою Ю.В. Бас, що «фінансова стратегія підприємства являє собою систему довгострокових цілей фінансової діяльності підприємства, обумовлених його фінансовою ідеологією, і найбільш ефективних шляхів їх досягнення» [2, с. 74] та продукуємо розкриття етапності в частині формування сприятливого інвестиційного клімату та конкурентоспроможності.

Під фінансовою стратегією в системі забезпечення конкурентоспроможності підприємства будемо розуміти загальний план окреслення точковості фінансових цілей та завдань на довгострокову перспективу через формування фінансових ресурсів у векторному напрямку фінансовою стійкості.

В процесі теоретичного опрацювання нами виокремлено ключові аспекти фінансової стратегії, які передують етапам формування та реалізації на підприємстві (рис. 1).

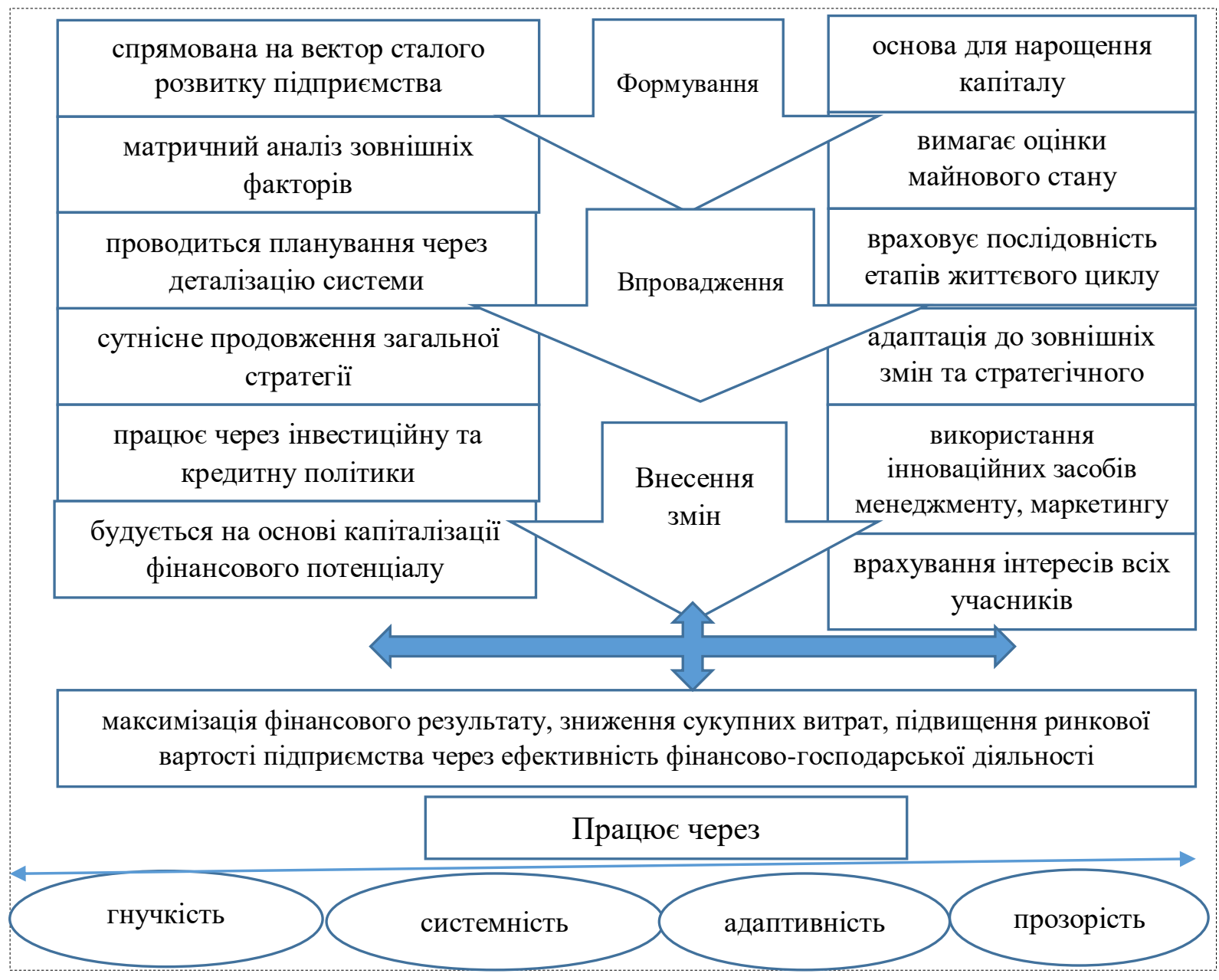

Рис. 1. Теоретичний аспект розбору сутнісного наповнення фінансової стратегії в процесі формування, реалізації та коригування

Дослідження засвідчили різні підходи до структури фінансової стратегії. Ми пропонуємо розглядати як структуровану систему через окреслення точковості іiі складових, які в сукупності працюють на загальний результат, забезпечують виконання мети, місій, цілей розвитку підприємства та створюють конкурентні переваги на ринку. До структурних елементів фінансової стратегії в частині результативності відносимо: 
1. Стратегію наповнення фінансовими коштами, яка працює через формування достатнього обсягу власних джерел фінансування та обсягу позикових коштів в частині управління та формування їх оптимальної структури.

2. Стратегію створення інвестиційного клімату, яка працює через розподіл інвестиційних фінансових ресурсів та їх капіталізацію.

3. Стратегію забезпечення стійкості в напрямку безпеки, що працює через управління ринковою вартістю, структурою капіталу, грошовими ресурсами та нейтралізацію ризиків понесених в процесі фінансово-господарської діяльності.

4. Стратегію підвищення якості фінансового менеджменту, що працює через планування, забезпечення і контроль в частині якісного ефективного управління в процесі формування управлінської структури (формування soft skills, бізнесової культури, партнерської взаємодії, комунікації, інноваційних фінансових технологій).

5. Стратегію оптимізації податкового навантаження, яка працює через зниження податкових ризиків, використання системи пільг, уникнення пені та штрафів.

Системний синтез структурних елементів фінансової стратегії в частині результативності залежить від результатів фінансово-господарської діяльності підприємства, та має право бути розширеним або модифікованим.

3 огляду на прикладні результати дослідження підприємства потребують формування чіткої послідовності ведення діяльності з метою зниження сукупних ризиків та освоєння нових ринків збуту через створення привабливого інвестиційного середовища та здоровою конкуренції.

I так, погоджуємось 3 теоретичним дослідженням Волощук Л.О. «що розробка та імплементація ефективної фінансової стратегії є основою для виходу підприємств 3 кризи. Основними властивостями фінансової стратегії $\epsilon$ iї результативність, адекватність, надійність, здатність створювати і підтримувати довгострокові конкурентні переваги, орієнтованість у часі, досяжність, зумовлену відповідністю потенціалу його стратегічним можливостям функціонування і розвитку, плановість, диференційованість, ризикованість» [3, с. 27].

Тому, формування фінансової стратегії $є$ для підприємства трудомістким процесом, так як залучаються абсолютно всі ресурси та робота ведеться в єдиному напрямку напрацювання спільного бачення конкурентного розвитку підприємства. Тобто, куди рухатись та якими цілями мотивуватись.

В першу чергу, в систему закладають достатній обсяг фінансових ресурсів, методи ефективності використання капіталу, оптимізація його структури та швидке реагування й нейтралізація ризиків на довгострокову перспективу.

Фінансова стратегія передбачає певну етапність в частині формування через аналіз середовища в частині збору інформації, аналіз та оцінку показників та прийняття ефективного управлінського рішення щодо використання фінансової тактики як короткострокового інструменту стратегії (табл. 1).

Тобто, грунтуючись на запропонованому підході системного формування фінансової стратегії в системі забезпечення конкурентоспроможності підприємства 3 метою максимально ефективного результату в стратегію закладаємо структурні елементи, які працюють лише у взаємозв'язку. Кожен тип фінансової стратегії реалізується через фінансові важелі та індикатори ефективності і впливу на результат.

Фінансова стратегія в частині результативності діє через принципи та етапність щодо формування і впровадження та працює за виведеним алгоритмом

Управління = капітал + активи + інвестиції + грошові коити прибуток + ризики

Саме, узгодженість та ефективність управління на кожному етапі дозволяє створювати вектор прибутковості в процесі розробки гнучкої фінансової політики підприємств. 
Таблиця 1

Архітектура формування фінансової стратегії підприємства

\begin{tabular}{|c|c|c|c|c|c|c|c|c|}
\hline \multirow{2}{*}{$\begin{array}{c}\text { Tun } \\
\text { фінансової } \\
\text { стратегії }\end{array}$} & \multicolumn{5}{|c|}{ Фінансові важелі реалізациї } & \multirow[b]{2}{*}{$\begin{array}{c}\text { Принциипи } \\
\text { формування }\end{array}$} & \multirow{2}{*}{$\begin{array}{c}\text { Індикатори } \\
\text { ефективності та } \\
\text { впливу на результат }\end{array}$} & \multirow{2}{*}{$\begin{array}{c}\text { Етапність щчодо формування } \\
\text { та впровадження }\end{array}$} \\
\hline & $\begin{array}{c}\text { Податкова } \\
\text { політика }\end{array}$ & $\begin{array}{l}\text { Інноваційна } \\
\text { політика }\end{array}$ & $\left|\begin{array}{c}\text { Iнвестиційна } \\
\text { політика }\end{array}\right|$ & $\begin{array}{c}\text { Дивідендна } \\
\text { політика }\end{array}$ & $\begin{array}{l}\text { Кредитна } \\
\text { політика }\end{array}$ & & & \\
\hline $\begin{array}{c}\text { Стратегія } \\
\text { наповнення } \\
\text { фінансовими } \\
\text { коштами }\end{array}$ & & & & $\begin{array}{c}\text { Механізм } \\
\text { розподілу } \\
\text { прибутку, тип } \\
\text { політики, склад } \\
\text { акцінерів, } \\
\text { вартість акцій }\end{array}$ & & $\begin{array}{c}\text { функціонування, } \\
\text { збалансованості, } \\
\text { системності, ефективності, } \\
\text { відповідальності, } \\
\text { планування } \\
\end{array}$ & $\begin{array}{c}\text { Зміна реінвестованого } \\
\text { прибутку, дивідендний } \\
\text { дохід, управління } \\
\text { структурою капіталу, } \\
\text { капіталізація прибутку } \\
\end{array}$ & $\begin{array}{l}\text { 1. «Ретроспективний аналіз } \\
\text { стратегій } і \text { особливостей їх } \\
\text { моделювання } \\
\text { 2. Формування стратегічних }\end{array}$ \\
\hline $\begin{array}{c}\text { Стратегія } \\
\text { забезпечення } \\
\text { стійкості }\end{array}$ & & $\begin{array}{c}\text { Інноваційна } \\
\text { активність, } \\
\text { інноваційний } \\
\text { потенціал, } \\
\text { інноваційні } \\
\text { фінансові } \\
\text { інструменти }\end{array}$ & & & $\begin{array}{l}\text { Умови } \\
\text { кредитування, } \\
\text { термін, розмір, } \\
\text { вартіст, } \\
\text { реінвестування, } \\
\text { система знижок }\end{array}$ & $\begin{array}{c}\text { дивідендної керованості, } \\
\text { оріснтованості на } \\
\text { стратегічні цілі, } \\
\text { фінансово-економічного } \\
\text { розвитку, максимізації, } \\
\text { капіталізації }\end{array}$ & $\begin{array}{c}\text { Рентабельність власного } \\
\text { капіталу, виробнича, та } \\
\text { фінансово-економічна } \\
\text { ефективність } \\
\text { Зміни витрат, обсяги } \\
\text { продажу продукції в } \\
\text { кредит, період окупності } \\
\text { інвестицій } \\
\end{array}$ & 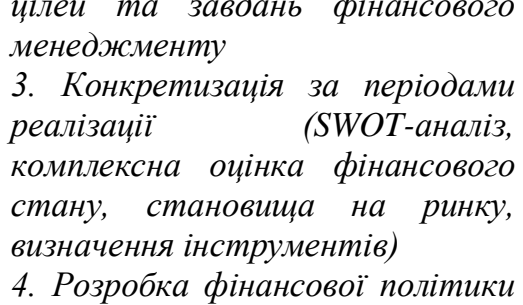 \\
\hline $\begin{array}{c}\text { Стратегія } \\
\text { створення } \\
\text { інвестиційного } \\
\text { клімату }\end{array}$ & 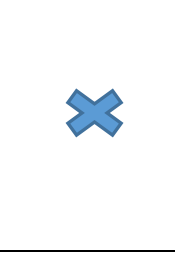 & 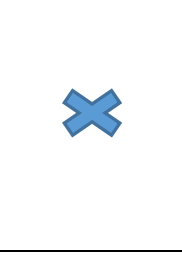 & $\begin{array}{l}\text { Інвестиційний } \\
\text { потенціал, } \\
\text { ризики, } \\
\text { приваливість, } \\
\text { активність, } \\
\text { клімат }\end{array}$ & & & $\begin{array}{l}\text { інвестиційної керованості, } \\
\text { комплексності, } \\
\text { інтегрованості, взаємодії, } \\
\text { відповідальності, } \\
\text { довгостроковості, } \\
\text { структурності, } \\
\text { орієнтованості } \\
\end{array}$ & $\begin{array}{c}\text { Зміна прибутку за рахунок } \\
\text { інвестицій, рентабельність } \\
\text { інвестицій, ефективність } \\
\text { капітальних і фінансових } \\
\text { вкладень }\end{array}$ & 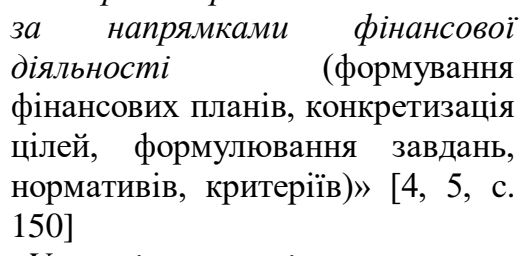 \\
\hline $\begin{array}{c}\text { Стратегія } \\
\text { підвищення } \\
\text { якості }\end{array}$ & & $\begin{array}{l}\text { Інноваційна } \\
\text { активність } \\
\text { через }\end{array}$ & & & & $\begin{array}{c}\text { безперервності, } \\
\text { альтернативності, } \\
\text { динамічності, гнучкості, }\end{array}$ & $\begin{array}{l}\text { Використання інноваційних } \\
\text { технологій, автоматизація, }\end{array}$ & $\begin{array}{c}\text { Управління = капітал }+ \text { активи } \\
+ \text { інвестиції }+ \text { грошові кошти } \\
\text { прибуток }+ \text { ризики }\end{array}$ \\
\hline $\begin{array}{c}\text { фінансового } \\
\text { менеджменту }\end{array}$ & & $\begin{array}{l}\text { лідерство та } \\
\text { комунікацію }\end{array}$ & & & & $\begin{array}{l}\text { цілеспрямованості, } \\
\text { партнерської взаємодії, } \\
\text { відповідальності }\end{array}$ & пропрацювання soft skills & \begin{tabular}{llr} 
5.«Оиінка & \multicolumn{2}{c}{ ефективності } \\
розробленої & стратегіï & за \\
параметрами & (узгодженість & iз
\end{tabular} \\
\hline $\begin{array}{c}\text { Стратегія } \\
\text { оптимізаиії } \\
\text { податкового } \\
\text { навантаження }\end{array}$ & $\begin{array}{c}\text { Рівень тягаря, } \\
\text { ставки } \\
\text { податків, } \\
\text { податкові } \\
\text { пільги та } \\
\text { ризики }\end{array}$ & & & & & $\begin{array}{c}\text { врахування впливу } \\
\text { фінансового ризику, } \\
\text { реагування, чіткості, } \\
\text { прозорості, } \\
\text { відповідальності, } \\
\text { гнучкості, адаптації }\end{array}$ & $\begin{array}{c}\text { Ефективність } \\
\text { оподаткування операційної } \\
\text { діяльності, податкова } \\
\text { місткість реалізації } \\
\text { продукції }\end{array}$ & $\begin{array}{lr}\text { загальною стратегією, зі зміною } \\
\text { зовнішнього } & \text { середовища, } \\
\text { внутрішня } & \text { збалансованість, } \\
\text { ресурсне } & \text { забезпечення, } \\
\text { оптимізація рівня ризиків», )» }[4, \\
5 \quad \text { с. } 150] & \text { моніторинг } \\
\text { ефективності). } & \end{array}$ \\
\hline
\end{tabular}


Тому, важливо при стратегічному планування з дотриманням етапності в системі забезпечення конкурентоспроможності використовувати матрицю вибору фінансової стратегії через синергію та дисбаланс 3 визначенням рівня ефективності кожного структурного елементу (рис. 2).

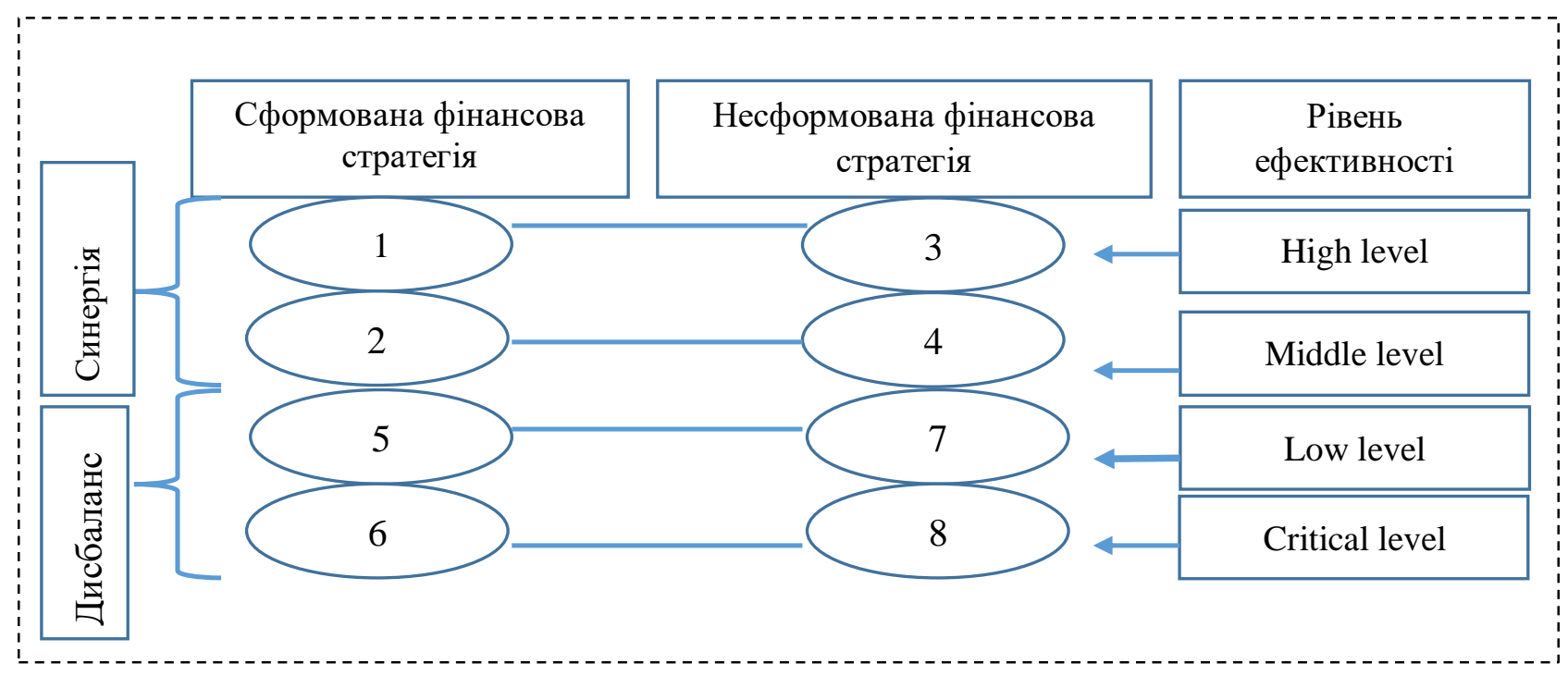

Рис. 2. Матриця вибору фінансової стратегії в частині ефективного стратегічного управління

де, 1 - тактика розвитку інноваційної діяльності 2 - тактика нарощення фінансового потенціалу

3 - тактика ефективних дій без чіткого плану

4 - асиметрична тактика без плану

5 - тактика лімітованого вектору потенціалу

6 - тактика інтеграції минулих дій

7 - тактика невизначеності дій

8 - тактика плагіату
Успіх в минулому + успіх в майбутньому

Успіх в минулому + сумніви

Точковість тоді $=$ вектор зараз

Невизначеність + неефективність

$$
=\text { збитки }
$$

Фінансова стратегія в системі забезпечення конкурентоспроможності потребує інструментів які б працювали на фінансовий ефект в довгостроковій перспективі. Реалізація вказаних заходів призведе до соціально-економічного ефекту через зростання валового прибутку та довіри з боку інвесторів.

Висновки. Фактично, фінансова стратегія $є$ тією основою, яка забезпечує векторне фінансове підгрунтя для фінансово-економічного розвитку в частині нарощення прибутковості. Ї̈̈ ефективність окреслюється моментами, за яких стратегічні цілі грунтуються на реальних фінансових показниках та можливостях підприємства, чіткій системі управління, гнучкості та прозорості.

Сьогодні, в умовах невизначеності робимо висновки, що підприємству доцільно посилювати інноваційний потенціал в частині запровадження ефективних систем маркетингу та менеджменту. Подібні напрямки векторно будуть нарощувати прибутковість, формувати лідерські і конкретні позиції на ринку агропромислової галузі, точково підсилять показники рентабельності та фінансової стійкості, закладуть основи до створення площини відкритості та прозорості. 


\title{
Список бібліографічного опису:
}

1. Ногіна С., Шумікін С., Костанян С. Аналіз структури і функцій власного капіталу підприємства. Економічний аналіз. 2012. Випуск 10. Частина 3. С. 346-349.

2. Бас. Ю.В., Зикова Г.В. Теоретичні основи формування фінансової стратегії підприємства. Наука й економіка. 2016. № 1 (41). С. 73-77.

3. Волощук Л.О. Фінансова стратегія в управлінні розвитком та економічною безпекою підприємств. Економічний журнал Одеського політехнічного університету. 2017. №1 (1). С. 23-30.

4. Стратегія i тактика фінансового менеджменту. Електронний pecypc. URL: https://pidruchniki.com/14350120/finansi/strategiya_taktika_finansovogo_menedzhmentu (дата звернення: 07.06.2020).

5. Корпан О.С. Фінансова стратегія підприємств легкої промисловості: принципи формування та особливості реалізації. Моделювання регіональної економіка. 2012. № 1. С. 143-160.

\section{References:}

1. Nogina S., Shumikin S., Kostanyan S. Analysis of the structure and functions of equity of the enterprise. Economic analysis. 2012. Issue 10. Part 3. pp. 346-349.

2. Bass Yu., Zikova G. Theoretical bases formation of financial strategy of the enterprise. Science and economics. 2016. № 1 (41). pp. 73-77.

3. Voloshchuk L. Financial strategy in the management of development and economic security of enterprises. Economic Journal of Odessa Polytechnic University. 2017. №1 (1). pp. 23-30.

4. Strategy and tactics of financial management. Electronic resource. URL: https://pidruchniki.com/14350120/finansi/strategiya_taktika_finansovogo_menedzhmentu (access date: 07.06.2020).

5. Korpan O. Financial strategy of light industry enterprises: principles of formation and features of realization. Modeling of the regional economy. 2012. № 1. pp. 143-160.

Дата подання публікації 20.06.2020 p.

УДК 336.145.2:364.2

Іщук Л.І., к.е.н., доцент

Ishchuk L. Candidate of Economic Sciences, Associate Professor https://orcid.org/0000-0002-1724-0292

Дацюк Ю.С., здобувач вищої освіти першого (бакалаврського рівня) Datsyuk Y. graduate of the first (bachelor's level)

\section{РОЛЬ МІСЦЕВИХ БЮДЖЕТІВ У ФІНАНСУВАННІ СОЦІАЛЬНОЇ СФЕРИ: ТЕОРЕТИЧНІ ТА ПРАКТИЧНІ АСПЕКТИ}

\author{
Луцький національний технічний університет
}

В статті досліджено дефініції категорії «місцеві бюджети», розглянуто комплексний системний підхід до поняття «місцеві бюджети» 3 позиції фінансів, юридичної, політичної, економічної теорії, організації та управління. Обгрунтовано, що поняття «місцеві бюджети» являє собою складну багатоаспектну категорію.

Окреслено основні завдання соціальної політики. Зазначено, що сучасна бюджетна політика зберігає за собою спрямованість до здійснення значного рівня видатків на соціальну сферу. Разом з тим, в умовах обмеженості фінансових ресурсів актуалізується питання розвитку регіону.

Визначено основні проблеми фінансового забезпечення соціальної сфери. Розвиток соціальної сфери потребує вагомого та довготривалого державного фінансування. Зростання соціальних видатків обумовлює скорочення ресурсів спрямованих на економічний розвиток. Проте розвиток саме соціальної інфраструктури (освіта, охорона здоров'я, інформатизація, транспортні та житлово-комунальні послуги, ін.) визначає рівень життя населення та напрямок розвитку регіону.

Зазначено, що в даний час головними проблемами в бюджетній сфері залишаються: забезпечення збалансованості бюджетів; вдосконалення засад регулювання бюджетними ресурсами; зміцнення системи фінансового контролю за цільовим, економічним і ефективним використанням бюджетних коштів; розробка методологічних підходів, методів і методик формування та розподілу бюджетних коштів; вироблення підходів до виконання бюджету у повній мірі тощо.

Обгрунтовано можливості щодо покращення рівня фінансового забезпечення соціальної сфери місцевими бюджетами.

Ключові слова: місиеві бюджети, видатки, фінансове забезпечення, соціальна сфера. 